\title{
BIOMECHANICAL ASPECTS OF FEMORAL FRACTURES IN AUTOMOBILE ACCIDENTS
}

\author{
S. RASTOGI, B. R. WILD, R. B. DUTHIE
}

From the Nuffield Orthopaedic Centre, Oxford

\begin{abstract}
A medical and engineering study was made of 1074 car accidents involving 2520 vehicle occupants. The injuries they sustained were correlated with details of the crash and with contact points inside the cars. Where possible the forces which were generated in the crash were estimated and related to the injuries.

In all, 39 car occupants suffered femoral shaft fracture, with an incidence of $1.7 \%$ and $0.8 \%$ for front and rear seat occupants respectively. Of these, 31 had associated injuries to other regions of the body; these were the cause of 13 of the 14 deaths in this group. Associated injuries were more severe in car occupants who were not wearing seat belts but the incidence of femoral fracture was not significantly different.

The mean velocity change (delta-V) causing femoral fracture was $26 \mathrm{mph}(42 \mathrm{~km} / \mathrm{h})$ and there was a higher incidence of femoral shaft fracture when delta- $V$ was over $30 \mathrm{mph}$. Estimates of forces needed to cause fracture were higher than those found in cadaver studies. The time to union of femoral fractures did not correlate with the severity of the crash but was longer (mean 19 weeks) than the average for other femoral fractures.
\end{abstract}

Despite increased emphasis on safety and stricter laws and regulations, automobile accidents continue to produce injuries. These often involve the lower limbs, and femoral shaft fractures are among the most common serious injuries (Kulowski 1964; Grattan and Hobbs 1968; Gloyns et al. 1979). In the late nineteenth century, Van Meyer, Roux and Wolff made the first studies of the mechanical properties of bone (Evans 1957). As regards the force causing a fracture, Küntscher in 1934 (Evans 1957) and more recently Melvin et al. (1975) and Viano (1977) showed that the peak force applied to the bone cannot be used alone as a single predictor; all available energy or momentum must be known. Patrick, Kroell and Mertz (1965) and Viano and Stalnaker (1980) have described the manner in which dynamically applied forces cause the displacement of whole body segments, whereas direct compression and shear applied to single regions of the body cause localised deformation and hence local injury. The early peaking of forces is predominantly an inertial reaction, and not causally associated with injury production.

S. Rastogi, MS Orth, Research Fellow, Oxford Road Accident Group B.R. Wild, BSc, Research Assistant, Oxford Road Accident Group R.B. Duthie, CBE, MA, ChM, FRCS, Nuffield Professor of Orthopaedic Surgery

Nuffield Orthopaedic Centre, Headington, Oxford OX3 7LD, England.

Correspondence to Mr B.R. Wild.

(C) 1986 British Editorial Society of Bone and Joint Surgery $0301-620 \mathrm{X} / 86 / 5147 \$ 2.00$
These earlier studies were made on either stripped femora in vitro or on cadavers. Situations involving patients are much more complex and the outcome of an automobile accident will depend on various factors associated with both the occupant and the vehicle. We have studied the relationship between the damage to the vehicle, the severity of the crash, the direction of impact, and injury to vehicle occupants. The mechanism of the production of femoral shaft fractures has been determined and the forces estimated.

\section{MATERIAL AND METHODS}

In all, 2520 car occupants involved in 1074 accidents taking place between April 1979 and June 1981 were studied. Accidents were investigated only if at least one vehicle was damaged enough to require being towed away from the scene. The vehicles from 444 accidents were examined at the site of the accident and from 630 accidents they were inspected at garages within 48 hours of the crash. Measurements of vehicle damage (Fig. 1) were made and used with the CRASH 2 computer program (McHenry and Lynch 1976) to calculate the severity of the crash. This was expressed as the change of velocity during the collision, delta- $\mathrm{V}$, a more important factor than pre-impact velocity as regards the causation of injury. The CRASH 2 programme was not applicable to roll-over and side-swipe accidents.

The maximum vehicle decelerations, derived from controlled experimental crashes with known velocity change, were estimated. These figures, multiplied by the 
Table I. Incidence of lower limb injury and femoral shaft fracture in occupants according to their position in the car

\begin{tabular}{lcclll}
\hline & & & \multicolumn{3}{l}{ With femoral shaft fracture } \\
\cline { 5 - 6 } Position in car & All occupants & With leg injuries & Number & \% of limb injuries & \% of all occupants \\
\hline Driver & 1534 & 481 & 25 & 5.2 & 1.6 \\
Front seat passenger & 580 & 199 & 11 & 5.5 & 1.9 \\
Rear seat passenger & 384 & 99 & 3 & 3.0 & 0.8 \\
Unknown & 22 & 12 & - & - & - \\
All positions & 2520 & 791 & 39 & 4.9 & 1.5 \\
\hline
\end{tabular}

body weight of the casualty, gave an approximation of the total forces that would have acted on the whole body at the time of the crash had the casualty not moved within the vehicle. Since the forces are variously distributed, and the deceleration experienced by the casualty when he is thrown forward against the interior surfaces of the car will not be the same as that of the car itself, results have been expressed in order-of-magnitude estimates.

The injuries sustained by the occupants of the car were recorded within 24 hours of their admission to hospital and all radiographs were studied. Postmortem examination was made of all fatal cases.

The type of trauma which had caused a femoral fracture was determined from inspection of the vehicle and the location of other injuries. Impact on the knee joint, caused by the casualty being thrown forward into the front structures of the car, was recorded as an indirect injury to the femur. A blow on the thigh from an intruding structure such as a door, a side pillar or the steering column was recorded as a direct injury.

\section{RESULTS}

Of 2520 car occupants studied, 791 (31.4\%) had lower limb injuries; only $39(4.9 \%)$ had fractures of the femoral

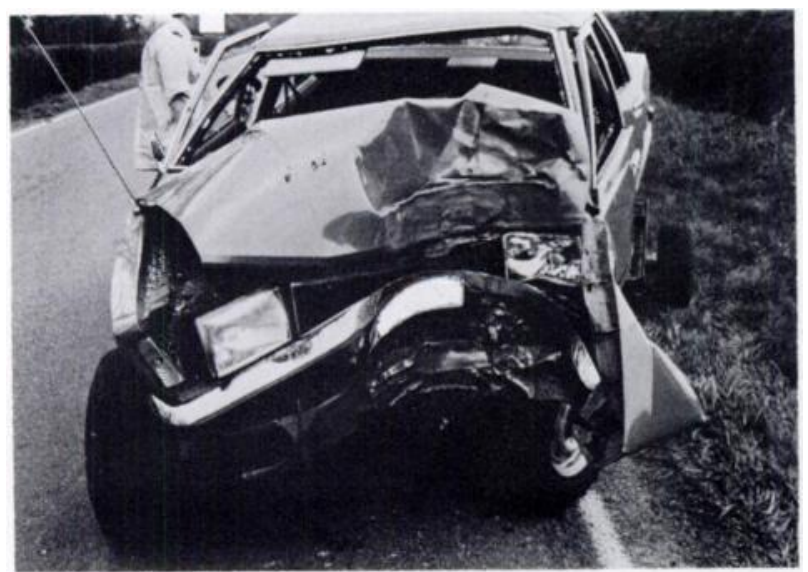

Fig. 1

Damage to the car in a collision which caused a femoral shaft fracture. shaft. Of these 39 casualties, 25 were drivers, 11 were front seat passengers and 3 were rear seat passengers (Table I). The male to female ratio of the group was $2: 1$, and $75 \%$ were aged from 16 to 45 years (Fig. 2 ); 14 occupants died, 13 at the scene of the accident and one in hospital from pulmonary embolism. The type and nature of the fractures were not known when death occurred at the scene of the accident; of the other 26 femoral fractures 5 were open and 21 closed. Most fractures (22 of 26), were comminuted oblique or segmental, three were comminuted transverse and one was spiral. Unilateral fracture of the shaft of femur was the only lower limb injury in 20 of the 39 casualties, including all three rear

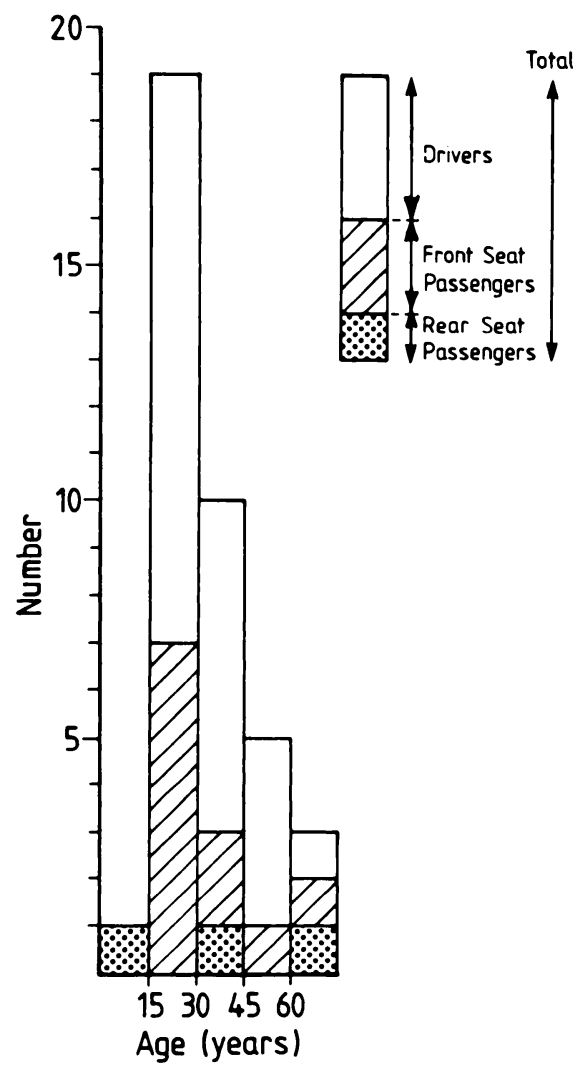

Fig. 2

The age distribution of 39 car occupants who suffered a femoral shaft fracture. 
Table II. Details of seating position, use of seat belt, and location of car occupants who sustained a femoral shaft fracture. Numbers in parentheses refer to the 14 killed by the accident

\begin{tabular}{|c|c|c|c|c|c|c|}
\hline \multirow[b]{2}{*}{ Site(s) of associated injuries } & \multicolumn{2}{|l|}{ Driver } & \multicolumn{2}{|c|}{ Front seat passenger } & \multirow[b]{2}{*}{ Rear seat passenger } & \multirow[b]{2}{*}{ All occupants } \\
\hline & Belted & Unbelted & Belted & Unbelted & & \\
\hline Head only & $1(1)$ & $6(2)$ & - & $5(2)$ & 1 & $13(5)$ \\
\hline Chest only & 1 & - & - & - & - & 1 \\
\hline Two or three of head, chest and abdomen & $3(2)$ & $9(5)$ & 1 & $4(1)$ & - & $17(8)$ \\
\hline None & 3 & 2 & - & $1(1)^{*}$ & 2 & $8(1)$ \\
\hline All cases & $8(3)$ & $17(7)$ & 1 & $10(4)$ & 3 & $39(14)$ \\
\hline
\end{tabular}

- Cause of death was pulmonary embolism in hospital

Table III. Incidence of femoral shaft fracture by number and percentage of car occupants, related to seating position and type of impact

\begin{tabular}{|c|c|c|c|c|}
\hline \multirow[b]{2}{*}{ Type of impact } & \multicolumn{2}{|l|}{ Drivers } & \multicolumn{2}{|c|}{ Front seat passengers } \\
\hline & Belted & Unbelted & Belted & Unbelted \\
\hline Frontal & $\begin{array}{ll}6 & 2.3\end{array}$ & 122.6 & $1 \quad 1.1$ & 52.9 \\
\hline Side of casualty & $1 \quad 2.7$ & 34.4 & -- & 29.1 \\
\hline Other & 10.5 & 20.7 & -- & 31.7 \\
\hline All & 1.6 & 172.1 & 10.6 & 103.1 \\
\hline
\end{tabular}

Table IV. Cause of femoral fracture, whether due to direct (D), indirect (I) or unknown forces (NK) related to position in the car, use of seat belt and type of impact

\begin{tabular}{|c|c|c|c|c|c|c|c|}
\hline \multirow{3}{*}{$\frac{\text { Type of impact }}{\text { Frontal }}$} & \multicolumn{3}{|c|}{ Drivers } & \multicolumn{2}{|c|}{ Front seat passengers } & \multirow[b]{2}{*}{ Rear seat passengers } & \multirow{3}{*}{$\begin{array}{l}\text { Total } \\
26\end{array}$} \\
\hline & Belted & \multicolumn{2}{|c|}{ Unbelted } & Belted & Unbelted & & \\
\hline & $\begin{array}{ll}1 & D \\
5 & 1\end{array}$ & $\begin{array}{l}3 \\
9\end{array}$ & $\begin{array}{l}\text { D } \\
\text { I }\end{array}$ & $1 \quad I$ & $5 \quad I$ & 21 & \\
\hline Side & D & $\begin{array}{l}2 \\
1\end{array}$ & $\mathrm{DK}_{\mathrm{NK}}$ & - & $\begin{array}{ll}2 & D \\
1 & I\end{array}$ & $1 \quad I$ & 8 \\
\hline Roll-over & I D & 2 & NK & - & 1 NK & - & 4 \\
\hline Side-swipe & - & & - & - & $1 \quad I$ & - & 1 \\
\hline Total & 8 & 17 & & 1 & 10 & 3 & 39 \\
\hline
\end{tabular}

seat passengers. Two victims had bilateral femoral shaft fractures with associated fractures of the pelvis, while 17 had other associated lower limb fractures (Fig. 3).

All but eight of the 39 cases had associated injuries to the head, chest and/or abdomen, with a higher incidence among car occupants not wearing seat belts. All 14 occupants who died as a result of a crash were front seat passengers and only three of them had been wearing seat belts. All except one of these fatal cases had severe associated injuries of the head, chest or abdomen (Table II).

Femoral fractures in surviving patients were treated by skeletal traction in 15 cases, by closed or open intramedullary nailing in nine cases and by external fixation in one. Two patients required internal fixation with bone grafting for non-union after closed treatment.
In two cases there was delay in union for 40 weeks and 120 weeks, while one patient suffered re-fracture, with eventual union after 38 weeks. All other fractures united in 12 to 34 weeks (mean 19, s.d. 6 weeks). Five patients had late problems with ligamentous instability of the ipsilateral knee though only one patient had been diagnosed as having significant ligament damage at the initial examination.

A seat belt was used by only nine of the injured front seat occupants and none of the rear seat passengers. Among drivers the wearing of a seat belt made no significant difference to the incidence of femoral shaft fractures, but the incidence in front seat passengers was lower in those wearing a seat belt (Table III). Three drivers and three front seat passengers (all unbelted), were completely ejected from their vehicles. Three of 


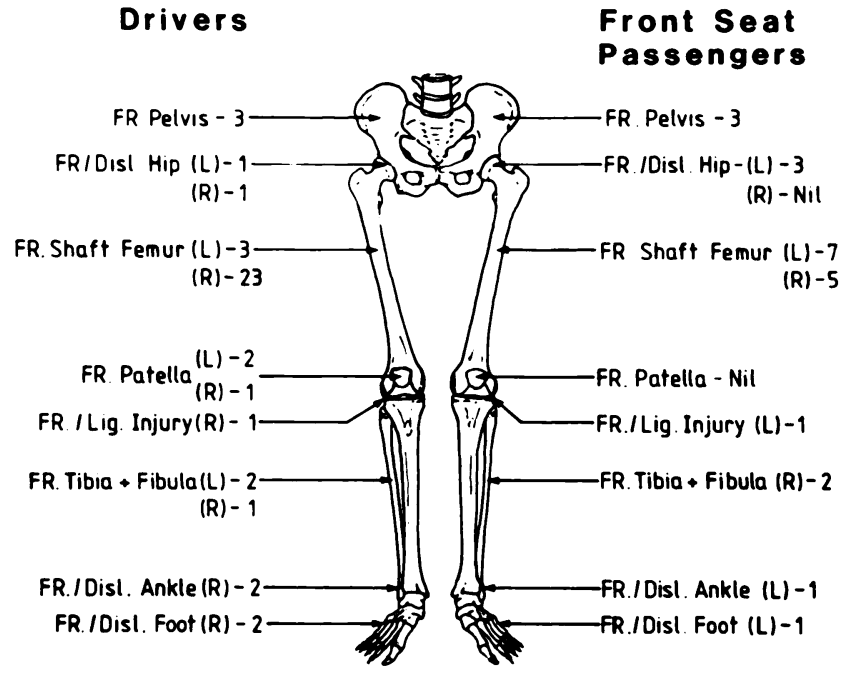

Fig. 3

Number and site of lower limb injuries in 25 drivers and 11 front seat passengers (FR, fracture; FR/Disl, fracture dislocation; FR/Lig.Injury, fracture and ligament injury).

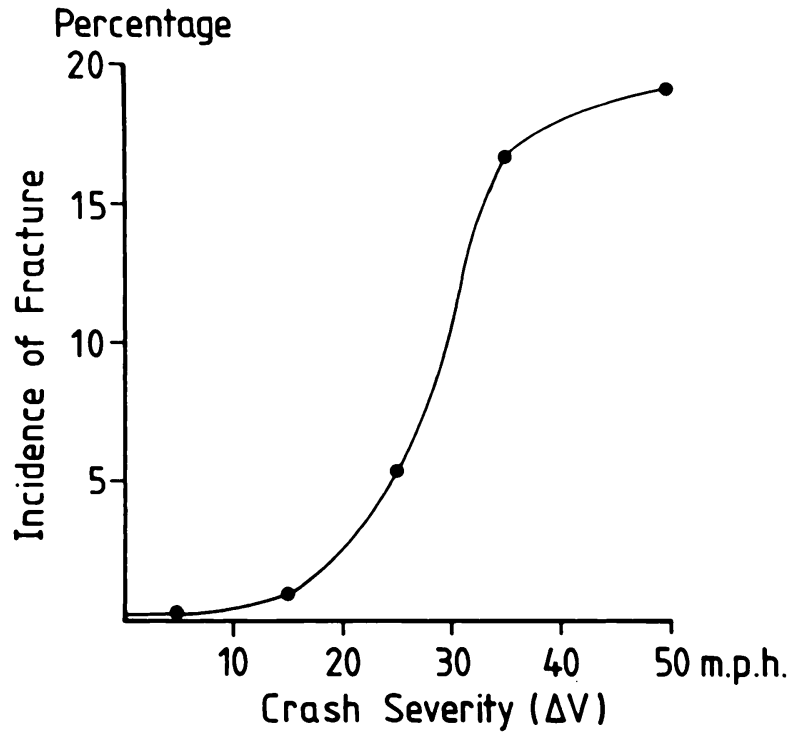

Fig. 4

To show the relationship between the severity of the crash and the incidence of femoral shaft fracture.

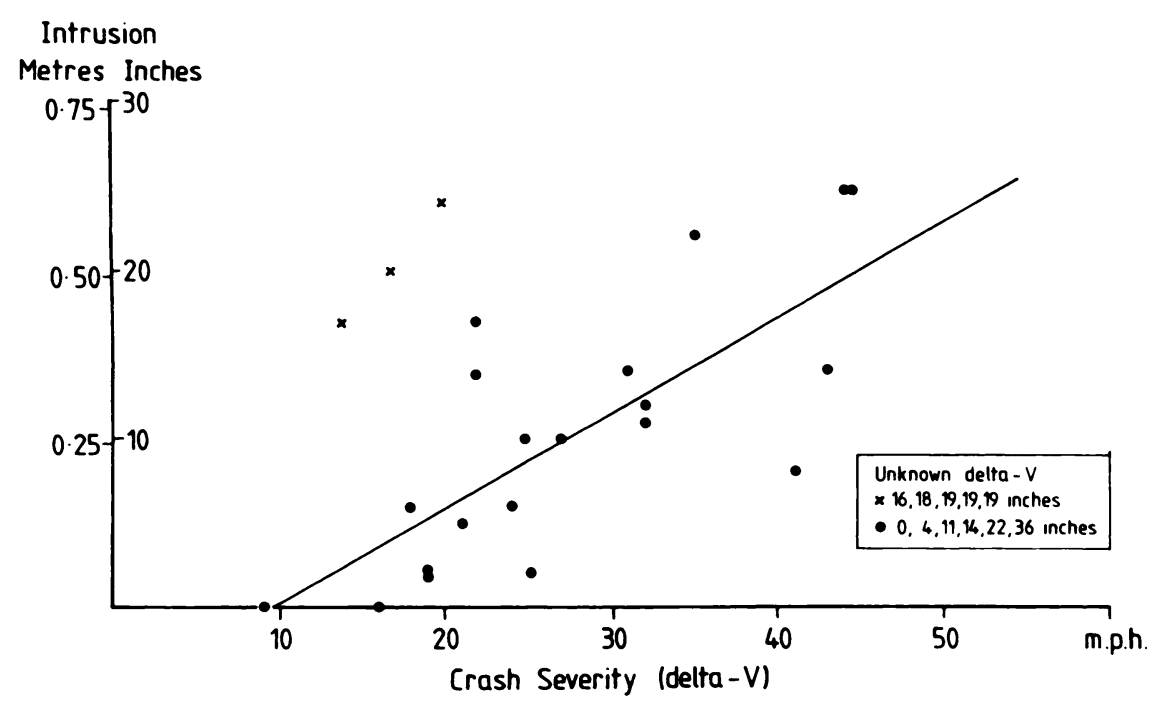

Fig. 5

To show the relationship between the severity of the crash and the intrusion into the vehicle for frontal collisions $(\bullet)$ and for side collisions $(\mathbf{x})$. The best straight-line fit for frontal impact points is shown.

these ejections happened in roll-over accidents, two in frontal collisions and one in a side impact.

The commonest type of collision causing femoral fracture was head-on or frontal (26 patients). Eight patients were injured in side impacts, seven of which were on the same side of the car as the casualty. Four femoral fractures, including three fatalities, were caused by roll-over accidents. Fractures of the femoral shaft were considered to be due to indirect loading in 24 cases, usually in frontal impacts, and to direct impact by side collision in only nine (Table IV).

The severity of the crash in terms of change of velocity (delta-V) was calculated for 23 cases and averaged $26 \mathrm{mph}(42 \mathrm{~km} / \mathrm{h})(\mathrm{s} . \mathrm{d} .10 \mathrm{mph}, 16 \mathrm{~km} / \mathrm{h})$. The probability of fracture of the shaft of femur was low when delta-V was less than $15 \mathrm{mph}(24 \mathrm{~km} / \mathrm{h})$, but increased to about $20 \%$ when crash severities exceeded $30 \mathrm{mph}(48 \mathrm{~km} / \mathrm{h})$ (Fig. 4). In side impacts the intrusion of the car body was severe, over 16 inches $(0.4 \mathrm{~m})$ in all instances, but it reached this extent in only six of the frontal impacts (Fig. 5). The intrusion was on the same side of the car as the casualty in 26 of the 34 accidents in which this was significant.

The structure which most frequently appeared to have caused the femoral fracture was the instrument panel or dashboard for front seat occupants and the back 


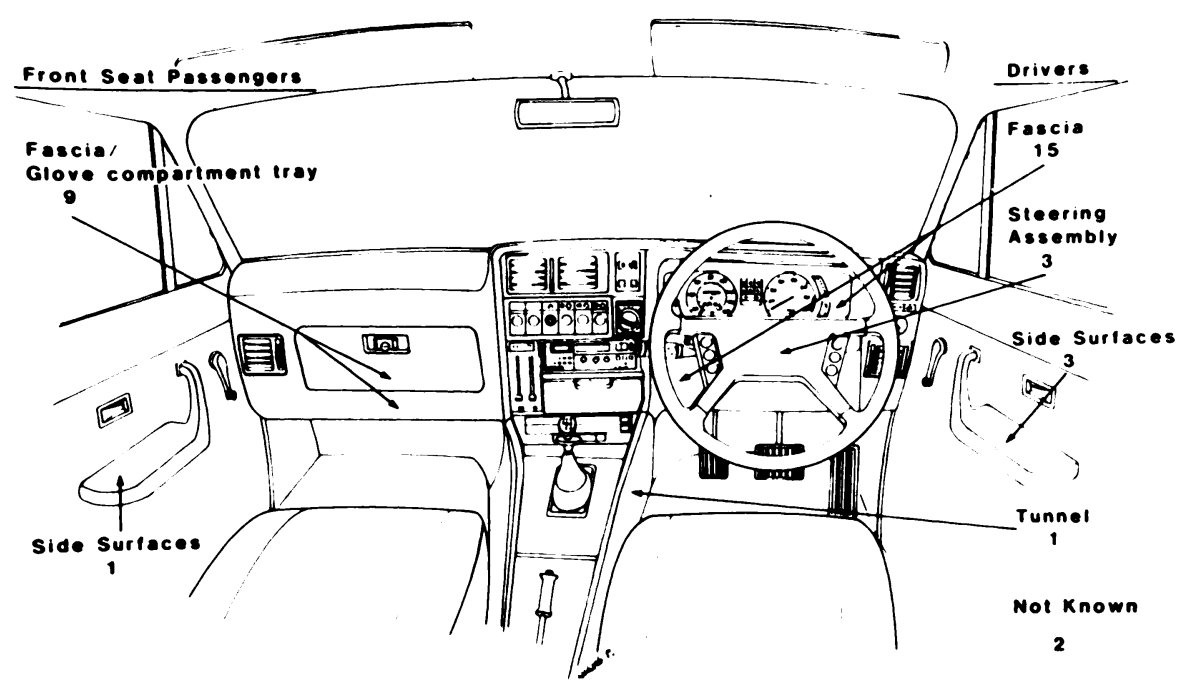

Fig. 6

Contact points within the vehicle which had given rise to fractures of the femoral shaft. Two fractures had been sustained after ejection from the vehicle, one in a driver and one in a front seat passenger.

of the front seat for rear seat passengers (Fig. 6). The structural source of injury could not be defined in two roll-over accidents which involved the ejection of car occupants.

In 14 cases of indirect loading of the femur, an estimate could be made of the order of magnitude of the decelerating force. This loading ranged from $8 \mathrm{kN}$ $(1800 \mathrm{lbf})$ to $26 \mathrm{kN}(5900 \mathrm{lbf})$ with a mean of $18 \mathrm{kN}$ (4000 lbf). This corresponds to maximum decelerations of 16 to 42 times the acceleration due to gravity on body masses of $45 \mathrm{~kg}$ to $127 \mathrm{~kg}$ ( $99 \mathrm{lb}$ to $279 \mathrm{lb}$ ).

\section{DISCUSSION}

In our series 39 of the 85 patients with severe injuries of the lower limbs had a fracture of the femoral shaft. This was mostly seen in the younger patients, a finding which supports the findings of Aldman (1970) and Chan, Kraus and Riggins. (1973). The male to female ratio among cases with a femoral shaft fracture was the same as that for all 2520 car occupants. Associated injuries to other parts of the body and to the same or opposite leg were seen in most cases (79.5\%) and in no case was a leg injury the only cause of a fatality. Car occupants not wearing seat belts were at more risk of severe injury, as was also observed by Marsh, Scott and Melvin (1975) and Hobbs (1981).

Femoral shaft fracture occurred in different types of impacts; frontal impact (involving $54 \%$ of all 2520 occupants) produced $67 \%$ of these fractures while side impact (involving 14\% of occupants) produced $20 \%$ of them. None of the car occupants involved in rear impacts sustained fracture of the femoral shaft.

In our small sample, there was no significant difference between the incidence of femoral shaft fracture among drivers wearing or not wearing seat belts. Belted front seat passengers, however, were found to be at less risk than unbelted front seat passengers and drivers in both frontal and side impact accidents $(p=0.14)$. This may be because the greater leg space available for front seat passengers than for drivers gave seat belts more space to operate and also because unbelted front seat passengers were more likely to be ejected from a car than unbelted drivers. The steering assembly may possibly prevent the ejection of unbelted drivers but does also provide an additional source of injury (Grattan and Hobbs 1968; Morris et al. 1982).

In side impacts, fractures of the femoral shaft are associated with a high bending moment caused by angulation of the bone over intruding side parts of the passenger compartment. In contrast to frontal impacts, therefore, the sideways velocity change of the car has only a secondary effect. The parameter which is most directly linked with the severity of injury in side impacts is the speed of the vertical surface of the struck vehicle at the instant at which it makes contact with the occupant (Cesari, Ramet and Herry-Martin 1978). Direct impact on the lateral thigh causes three-point bending of the femur, producing tensile and compressive strains on the medial and lateral sides of the bone respectively. These would tend to produce a transverse fracture with comminution or butterfly fragmentation on the lateral side at the point of impact. In a few cases it appeared that the thigh segment had become fixed between the fascia and the seat because of forward movement of the whole body, and the addition of force from a bent steering column produced a four-point bending strain on the femur.

The impact mark left by the occupant's knee on the dashboard or instrument panel was located in 19 of the 
Table V. Reports of the loading force required to fracture a femur

\begin{tabular}{|c|c|c|c|c|c|}
\hline \multirow[b]{2}{*}{ Authors } & \multirow[b]{2}{*}{ Subjects of study } & \multirow[b]{2}{*}{ Number } & \multicolumn{3}{|c|}{ Loading force $(k N)$} \\
\hline & & & Minimum & Maximum & Average \\
\hline Patrick, Kroell and Mertz 1965 & Embalmed cadavers & 10 & 8.7 & - & - \\
\hline \multirow[t]{2}{*}{ Powell et al. $(1974,1975)$} & Embalmed cadavers & 7) & \multirow{2}{*}{7.1} & \multirow{2}{*}{13.2} & \multirow{2}{*}{10.2} \\
\hline & Unembalmed cadavers & $2 \int$ & & & \\
\hline Melvin et al. (1975) & Unembalmed cadavers & 14 & 13.4 & - & - \\
\hline Present series & Road traffic accident casualties & 15 & 8 & 26 & 18 \\
\hline
\end{tabular}

cases considered in this study, and a possible mechanism of fracture surmised. In head-on impacts it is assumed that the body of the car occupant, unless it is constrained initially moves at the same speed as the vehicle and continues to move forward until it impacts with the car structure, suffering a "second collision" (Nagel, Burton and Manning 1977). In unbelted drivers this can produce the "three level injury" described by Weisz, Schramek and Barzilai (1974) or for front seat passengers "two level injury". For car occupants wearing seat belts, the injuries depend on whether the seat belt is worn properly and the severity of the crash.

At impact with the car structure soft tissue compression at the knee is followed by axial loading of the femur. Unbelted rear seat passengers or heavy luggage moving forward from the rear seats may cause further thigh loading (two cases of this were recorded in our study). Axial loading of the femur generates bending forces in anteroposterior and mediolateral planes (Powell et al. 1975; Viano and Stalnaker 1980). These strains have a combined effect causing compression medially and tension laterally (a beam bending effect); oblique impacts cause further exaggeration of the mediolateral bending of the femur. Anteroposterior bending gradually increases and, eventually, the anterior tensile strain exceeds the load-carrying ability of the compact bone and fracture takes place (Viano and Stalnaker 1980). In our study, comminution was more common on the posteromedial than the anterolateral cortex of the femur.

Frankel and Nordin (1980) have suggested that more rapid loading causes more absorption of energy by the bone, which is finally liberated explosively, and results in more comminution of the fracture. This mechanism, of rapid loading, energy absorption and liberation, would be expected in the accidents with high crash severity (delta-V) reported in this study. Figure 4 shows that nearly $20 \%$ of all car occupants subjected to a delta-V of over $30 \mathrm{mph}(48 \mathrm{~km} / \mathrm{h})$ suffered femoral shaft fractures. With one exception, in all instances of femoral fracture by frontal impact, the crash severity was more than $20 \mathrm{mph}(32 \mathrm{~km} / \mathrm{h})$; the exception involved a casualty who weighed $127 \mathrm{~kg}(279 \mathrm{lb})$ and was injured by direct impact with an intruded front vehicle structure and the steering column. In frontal impacts the severity of the intrusion into the passenger compartment increased with crash severity above a threshold delta-V of $16 \mathrm{mph}(26 \mathrm{~km} / \mathrm{h})$; in side impacts the intrusion could be quite large even at a lower severity of crash (Fig. 5).

For the last two decades various workers have tested cadavers, dummies and stripped femora in vitro, to determine the mechanism of human femoral shaft fractures in relation to the various stresses and strains produced in both static and dynamic impacts (Patrick et al. 1965; Patrick, Mertz and Kroell 1967; Powell et al. 1974, 1975; Melvin et al. 1975). In this study, the first to be carried out on patients, the decelerating forces were estimated to be greater on average than those calculated from cadaveric or experimental studies (Table V). The forces which we calculated were, however, only an indication of the order of magnitude of the loading involved on the whole body, and this is confirmed by the multiplicity of fractures found in our cases. The results are not surprising since Rybicki, Simonen and Weis (1972) demonstrated that muscle tension in the living human body can greatly reduce the mid-shaft bending stresses; tests on cadavers cannot take account of this effect. It is also true that cadaver studies have largely been on older age groups than most of the cases in our study, and it is reasonable to assume that higher forces would be required to injure the younger living body.

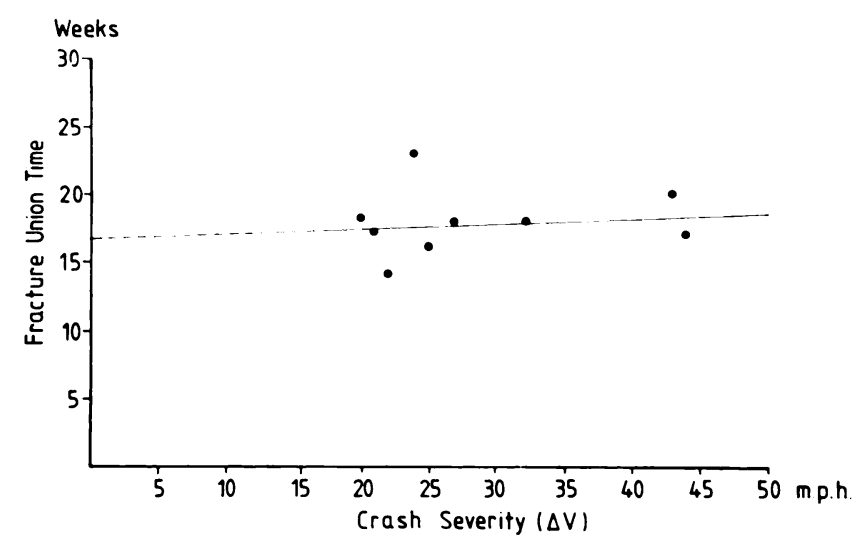

Fig. 7

Relationship between the severity of the crash causing femoral shaft fracture and the time to uncomplicated union. 
Severe comminution from high-energy trauma caused by severe crashes has been thought to lead to delayed union and non-union. We found no correlation between severity of crash and time to union among cases suffering high-energy impact (Fig. 7). The average healing time required was, however, greater than the average reported for femoral shaft fracture from other causes (Nichols 1963), and two of the 25 cases needed bone grafts for non-union.

Because of the complexity and multiplicity of the injuries in these cases, soft-tissue injury to the knee may be missed on initial examination and may well produce problems in the long term. This occurred in $17.3 \%$ of our patients; they had only minor bruises or grazes at the knee at the time of the accident, but showed significant ligamentous instability at follow-up. Ligamentous instability of the knee, as well as other factors such as leg shortening or deformity from malunion, leads to increased late morbidity and disability (Ritchey, Schonholtz and Thompson 1958; Nagel et al. 1977).

This has been a study of the epidemiology of trauma to human tissues, and of the tolerances involved. Detailed investigations of this type, from which the mechanisms of injury may be ascertained, can help understanding of the patient's injuries and therefore lead to improved care of patients. Knowledge of the mechanical forces involved, which can be obtained from vehicle deformation studies, can lead to modifications in vehicle design and help prevent some of these severe injuries and their consequences.

The work described in this paper was carried out under contract to the Transport and Road Research Laboratory, but the views expressed are those of the authors and are not necessarily those of the Transport and Road Research Laboratory, nor of any other part of the Department of Transport, or any other Government department.

\section{REFERENCES}

Aldman B. Road accidents in Sweden. J Trauma 1970;10:921-5.

Chan D, Kraus JF, Riggins RS. Patterns of multiple fracture in accidental injury. J Trauma 1973;13:1075-82.

Cesari D, Ramet M, Herry-Martin D. Injury mechanisms in side impact. Proceedings of Twenty-Second STAPP Car Crash Conference. New York: Society of Automotive Engineers, 1978:431-47.

Evans FG. Stress and strain in bones: their relation to fractures and osteogenesis. Springfield, Illinois: CC Thomas, 1957:9-15, 54-72.

Frankel VH, Nordin M. Basic biomechanics of the skeletal system. Philadelphia: Lea \& Febiger, 1980.
Gloyns PF, Hayes HRM, Rattenbury SJ, Thomas PD, Mills HC, Griffiths DK. Lower limb injuries to car occupants in frontal impacts. Proceedings of Fourth International IRCOBI Conference on Biomechanics and Serious Trauma, 1979:105-21.

Grattan E, Hobbs JC. Mechanisms of serious lower limb injuries to motor vehicle occupants. Ministry of Transport R.R.L. Report LR 201. Crowthorne: Road Reserach Laboratory, 1968.

Hobbs CA. Car occupant injury patterns and mechanisms. Supplementary report 648. Crowthorne: Accident Investigation Division, Safety Department, Transport and Road Research Laboratory, 1981.

Kulowski J. Fractures of the shaft of the femur resulting from automobile accidents. $J$ Int Coll Surg 1964;42:412-20.

Marsh JC, Scott RE, Melvin JW. Injury patterns by restraint usage in 1973 and 1974 passenger cars. Proceedings of the Nineteenth STAPP Car Crash Conference. New York: Society of Automotive Engineers Inc, 1975;45-78.

McHenry RR, Lynch JP. CRASH 2 user's manual. Springfield, Virginia: National Technical Information Service, 1976.

Melvin JW, Stalnaker AR, Alem NM, Benson JB, Mohan D. Impact response and tolerance of the lower extremities. Proceedings of the Nineteenth STAPP Car Crash Conference. New York: Society of Automotive Engineers Inc, 1975;543-59.

Morris JB, Stucki L, Morgan RM, Bondy N. Occupant protection from impact with the steering assembly. Ninth International Technical Conference on Experimental Safety Vehicles. National Highway Trafic Safety Administration: U.S. Department of Transportation, 1982;175-90.

Nagel DA, Burton DS, Manning J. The dashboard knee injury. Clin Orthop 1977;126:203-8.

Nichols PJR. Rehabilitation after fractures of the shaft of the femur. $J$ Bone Joint Surg [Br] 1963;45-B:96-102.

Patrick LM, Kroell CK, Mertz HJ Jr. Forces on the human body in simulation crashes. Proceedings of the Ninth STAPP Car Crash Conference. New York: Society of Automotive Engineers Inc, $1965 ; 237-59$.

Patrick LM, Mertz HJ Jr, Kroell CK. Cadaver knee, chest and and head impact loads. Proceedings of the Eleventh STAPP Car Crash Conference. New York: Society of Automotive Engineers Inc, 1967;106-17.

Powell WR, Advani SH, Clark RN, Ojala SJ, Holt DJ. Investigation of femur response to longitudinal impact. Proceedings of Eighteenth STAPP Car Crash Conference. New York: Society of Automotive Engineers Inc, 1974;539-56.

Powell WR, Ojala SJ, Advani SH, Martin RB. Cadaver femur responses to longitudinal impacts. Proceedings of Nineteenth STAPP Car Crash Conference. New York: Society of Automotive Engineers Inc, 1975;561-79.

Ritchey SJ, Schonholtz GJ, Thompson MS. The dashboard femoral fracture: pathomechanics, treatment and prevention. J Bone Joint Surg $[\mathrm{Am}] 1958 ; 40-\mathrm{A}: 1347-58$.

Rybicki EF, Simonen FA, Weis EB Jr. On the mathematical analysis of stress on human femur. J Biomech 1972;5:205-15.

Viano DC. Considerations for a femur injury criterion. Proceedings of Twenty-First STAPP Car Crash Conference. New York: Society of Automotive Engineers Inc, 1977;445-73.

Viano DC, Stalnaker RL. Mechanisms of femoral fracture. J Biomech 1980;13:701-5.

Weisz GM, Schramek A, Barzilai A. Injury to the driver. J Trauma $1974 ; 14: 212-5$. 